\title{
"Are Methods of Natural Science Suitable To Be Used In Social Science Including Linguistics?"
}

\author{
Srisna J. Lahay \\ \{srisna@yahoo.com\} \\ Fakultas Ilmu Pengetahuan Budaya, Universitas Indonesia, Jl. Margonda Raya, Pondok Cina, \\ Kecamatan Beji, Kota Depok, Jawa Barat 16424
}

\begin{abstract}
When reading the question in the title above, we, linguists, immediately answer that they are. We assume that social science IS a science. Therefore, it may have some of the characteristics that a natural science has, and in that way the methods of social science may also have some of the characteristics, if not all, of methods that a natural science has. But it is just an assumption. In this study the writer would like to discuss the answer to the question above in details. By examining the works of Bird (1998) and Poespowardojo (2015) about philosophy of science and Eriyanto (2001) about discourse analysis, the writer further discusses the answers to these following questions: What is science? What are the characteristics of science? What is natural science? What is social science? How do they differ? What is a scientific method? What are their characteristics? Can this scientific method be used in Linguistics as one of social sciences? The result of this examination confirms the assumption above. Linguistics, a study about language used by humans as a means of communication, IS a science because it is a conscious effort to investigate, discover, and increase human's understanding about a certain aspect of reality, that is language. It has several characteristics of science. It has a theory, method, and methodology. Linguistics is a socio-cultural or human science because it formulates an interpretative operation of social realities. Its method is a scientific method because it characterizes a science. It is general in its application. It is not dependent on imagination or intuition and can be applied by any skilled scientist. Its reliability can be found out based on a theoretical deduction. In its research, a linguistic model of analysis goes through the same scheme and procedure as any practice of natural science. It begins with defining the purpose of the research, goes on with designing the research and then collecting and analysing data, and ends with drawing the conclusion.
\end{abstract}

Keywords: linguistics, philosophy of science, natural science, scientific method, social science

\section{Introduction}

When reading the question whether methods of natural science are suitable to be used in social science, including Linguistics, we, linguists, immediately answer that they are. We assume that a social science IS a science. Therefore, it may have some of the characteristics that a natural science has, and in that way the method of social science may also have some of the characteristics, if not all, of method that a natural science has. But it's just a thought, an assumption. In this paper the writer would like to discuss the answer to the question in details. Therefore, the writer will further discuss the answers to these following questions: What is science? What are the characteristics of science? What is natural science? What is social 
science? How do they differ? And what is a scientific method? What are their characteristics? Can this scientific method be used in Linguistics as one of social sciences? At the end of this paper the writer will draw a conclusion that confirms the thought or assumption above.

\section{Research Methods}

This paper is an attempt to study Linguistics from a philosophical point of view. By examining the works of Bird [1] and Poespowardojo[2] about philosophy of science and Eriyanto[3] about discourse analysis, the writer further discusses the answers to questions about the concept of science and its characteristics, concept of natural and social science and their differences, concept of scientific method and its characteristics, and whether this scientific method can be used in Linguistics as one of social sciences.

\section{Results and Discussion}

According to Poespowardojo[2], a science is defined as a conscious effort to investigate, discover, and increase human's understanding of a certain aspect of reality. He then proposes several characteristics of science. First, a science is objective. It means that with a certain theory, method, and methodology, a scientific study arrives as an objective truth, that is an agreement between a concept about a general principle (theory) and reality as proven through a method used and that a scientific claim is based on facts, not on the subjective opinion of the scientist. Second, a science is methodical. It shows that in a scientific study a method helps a scientist follow a certain procedure so that there will not be a deviation in the process of finding the truth.

A method is used to prove a theory, so a theory, as a general concept which is going to be proven through a scientific procedure, must be clear. Third, a science is systematic. It means that a scientific study about an object follows a thorough theory in order to avoid a logical overlapping so that a cause-effect relationship, time sequence, bias and prejudice can be clearly seen, and as a result a scientific explanation about the object being studied can be intact, comprehensive, and integrated. Fourth, a science claims a universal truth. It shows that what is achieved by a science is a truth which can be generally accepted.

Poespowardojo[2] then states that a scientific knowledge can develop through specializations which intellectually classify empirical realities to scientific groups which can be explained according to a unified method. As a result, there are two major groups of sciences: natural sciences and human sciences.

According to Poespowardojo[2], natural sciences are based on positivism or empiricism. It shows that only empirical experiences can explain and prove that something is right or wrong. A theory is proven through a method which is called an empirical cycle, that is a scientific operation based on an inductive method. The steps of this method start with observations against individual cases, which result in empirical generalizations. From these generalizations a theoretical assumption or hypothesis can be tested. If the result of the test is right, the hypothesis is proven and becomes a theory, which can be used to generate what is needed by humans in their life.

Poespowardojo[2] adds rationalism to this scientific group. Rationalism emphasizes on the subjective awareness. The concept of awareness is the essence of rationalism or subjectivism. It makes a mathematical certainty as a scientific model. Empiricism refers to empirical evidence, 
while rationalism refers to pure reasoning. Both do not rely on a social authority or belief system. In other words, empiricism emphasizes on a real object (objectivism), while rationalism emphasizes on a subjective awareness (subjectivism). Both models of modern sciences emphasize on the explanatory aspect of questions on why and how something happens.

Human sciences or socio-cultural sciences appear as a reaction towards empiricism and rationalism of natural sciences, which emphasize on the explanatory aspect of why and how something happens. Human sciences formulate an interpretative operation towards social realities. This critical reconstruction on empiricism and rationalism results in theories of social criticism. Human sciences aim at reconstructing a scientific method that plays an important role in interpreting a cultural and socio-economic crisis in the post-modernism era. This group of sciences questions empiricism and rationalism as two theoretical systems that reduce a social reality as a mere objective fact or subjective will. The result is the proposition of a pluralism methodology that becomes the basis of various scientific research. In the perspective of this social criticism all kinds of sciences are understood as theories or concepts about realities, which need proving through methods.

Poespowardojo[2] mentions that a method is a procedure which involves a mode of reasoning, a form of social activity, which is historically institutionalized, and a system of meaning. He further states that a scientific method is a scientific logic, a sociological context, and a cultural implication, which determine a perspective or a world view. Bird[1] quotes what he calls the optimistic view of scientific method and states that a scientific method has these following features. It is distinctive of science. In other words, it characterizes science. It explains the progress and success of science. It is general in its application.

In other words, it is common to all parts of science. It is applicable in a methodical fashion. In other words, it is not dependent on imagination, intuition, etc. and can be applied by any reasonably skilled scientist. Its reliability can be known a priori, meaning in a way based on theoretical deduction rather than empirical observation. Bird[1] also states that methods are discoveries or applications of science and that a scientific method concerns with the context of justification, that is the testing, evaluation, and confirmation of theories is subject to rules and methods.

Bird[1] quotes Stuart Pocock on his practice of clinical trials. Pocock applies a scientific method to these clinical trials. He presents five steps in the scheme and procedures these trials involve: define the purpose of the trial (state specific hypotheses) $\square$ design the trial (a written protocol) $\square$ conduct the trial (good organization) $\square$ analyse the data (descriptive statistic, test of hypotheses) $\square$ draw conclusions (publish result). There are two aspects of particular interest in relation to this method. The first is the statistical interpretation of data and drawing inferences from it. The second is the emphasis on randomized and controlled trials. Randomization indicates that the allocation of patients to the control group or to the treatment group is random, whereas controlled trials indicate trials where one group is given treatment while another group is not. The effectiveness of the treatment will be measured by the difference in the result between the two groups.

Linguistics is the study about language used by humans to communicate. One of the theories used in Linguistics is Critical Discourse Analysis (CDA). According to Eriyanto[3], in CDA, a discourse, the use of language in a written or oral form, is understood not only as a study about language but also as a form of social practice. Quoting Fairclough and Wodak, Eriyanto[3] describes a discourse as a social practice resulting from a dialectical relation between a discursive event and a situation, institution, and social structure, which shape it. He further states that a CDA investigates how the existing social groups fight with each other and propose their own versions of it through language. One of the models of CDA is the one 
proposed by Norman Fairclough. As quoted by Eriyanto[3], this model of analysis is based on a big question: how can a text be related to a context in a society? Fairclough's attention is on language seen as a practice of power. Therefore, the analysis must focus on how language shapes and is shaped by a certain social relation and context, and as a result this model of analysis is also known as a social change model.

As quoted by Eriyanto[3], Fairclough divides a discourse analysis into three dimensions: text, discourse practice, and socio-cultural practice. In Fairclough's model, a text is analysed linguistically, by looking at its vocabulary, semantics, and grammar. These elements are analysed in order to find out these three problems: ideational, relation, and identity. The first problem, ideational, refers to a certain representation conveyed in the text, which carries a certain ideological content. The second problem, relation, refers to how a relation between a journalist and a reader is constructed.

The third problem, identity, refers to how the identity of the journalist and reader is constructed and how this identity is conveyed in the text. A discourse practice is another dimension that relates to the process of producing and consuming the text. A text is produced in a specific way and with a specific routine and structured work pattern. A text is consumed differently according to a different social context. A socio-cultural practice is a dimension that relates to the context outside the text. This context covers not only a situational context but also a context resulting from an institutional practice in relation to a certain society, culture, or politics.

Linguistics, a study about language used by humans as a means of communication, is a science because it is a conscious effort to investigate, discover, and increase human's understanding about a certain aspect of reality, that is language. It has several characteristics of science. It has a theory, method, and methodology. For example, Critical Discourse Analysis as a theory of the use of language has its model of analysis proposed by Norman Fairclough. With Fairclough's model of analysis, CDA arrives at an objective truth: the use of language is a social practice. It is methodical and systematic because it goes through a certain procedure in order to prove a theory and to come up with a scientific explanation that is intact, comprehensive and integrated, and its claim that language shapes and is shaped by a certain social relation and contex is generally accepted.

Recently, there is considerable focus on the embedding of identities, ideologies and attitudes in discourse practice since both individuals and groups conceptualise themselves to society through the framing of discourse. Therefore, the linguistic means employed in discourse play a major role in the ways these identities, ideologies and attitudes are presented, performed, enacted and embodied (Foucault, 1984). interaction and discourse influence one another by the "cognitive interface of mental models, knowledge, attitudes and ideologies" (van Dijk, 2009, p. 64). Vague language does not represent inadequacy of human language and, therefore, there is no reason to advocate vague language avoidance. Vague language could be as efficient as precise language (Jucker et al., 2003, p. 1738).

In the production of language, verbal or non-verbal, people are committed to clarity and precision. Sometimes, however, people override clarity and precision, intentionally or unintentionally, and produce less than the required information. Philosophers considered vague language as an indication of the speaker's limited knowledge (Williamson, 1994). In linguistics, vagueness is an intrinsic foundational feature of language (Raffman, 2014, p. 2) 


\section{Conclusion}

To sum up, Linguistics is a science. It is a socio-cultural or human science because it formulates an interpretative operation of social realities. Its method is scientific because, as Fairclough's method of CDA shows, it characterizes a science. It is general in its application. It is not dependent on imagination or intuition and can be applied by any skilled scientist. Its reliability can be found out based on a theoretical deduction. In a research, Fairclough's model of analysis goes through the same scheme and procedure as Pocock's practice of clinical trials. It begins with defining the purpose of the research, goes on with designing the research and then collecting and analysing data, and ends with drawing the conclusion.

\section{References}

[1] Alexander Bird, Philosophy of Science: Fundamentals of Philosophy. New York: Routledge, 1998.

[2] T. M. Soerjanto Poespowardojo and Alexander Seran, Filsafat Ilmu Pengetahuan: Hakikat Ilmu Pengetahuan, Kritik terhadap Visi Positivisme Logis, serta Implikasinya. Jakarta: Penerbit Buku Kompas, 2015.

[3] Eriyanto, Analisis Wacana: Pengantar Analisis Teks Media. Yogyakarta: LKiS, 2001 